\title{
Psychological meaning of the living room: a multidimensional attitudinal analysis
}

\author{
Elizabeth L Kempen
}

\section{Opsomming}

Mense se ervaring van 'n plek, soos ' $n$ woonkamer, is nog nie ondersoek met betrekking tot die sin wat mense van so 'n gedekoreerde vertrek maak of die betekenis wat hierdie gedekoreerde vertrek het nie. Een wyse om die betekenis van die voorkoms van 'n gedekoreerde vertrek soos die woonkamer te bepaal, is om 'n persoon se houding teenoor die gedekoreerde voorkoms van die plek te bepaal (Hanyu, 1997). Volgens Canter en Thorne (1972) is houdings sensitiewe sielkundige prosesse waarmee betekenis bepaal kan word. In besonder het Canter en Thorne (1972) en Devlin en Nasar (1989) bewys gelewer dat die betekenis van plekke (soos 'n woonkamer) deur mense se beoordelings van die voorkoms van 'n plek beïnvloed word. Daar word aan die hand gedoen dat dit moontlik is om die houding van mense teenoor ' $n$ gedekoreerde vertrek te bepaal. Die doel van hierdie studie is daarom om die betekenis van die gedekoreede woonkamer van nuwe huiseienaars te bepaal deur die houding teenoor die gedekoreerde woonkamer te ondersoek.

Die studie gebruik die voorkoms van 'n gedekoreerde woonkamer as stimulus waarmee mense se houdings teenoor hulle eie persoonlik gedekoreerde woonkamer bepaal kan word, aangesien die voorkoms van die woonkamer gereeld gedekoreer en gemodifiseer word (Caborn, 2001). Dit word aanvaar dat die nuut veranderde voorkoms betekenisvol is, wat dan die houding teenoor die gedekoreerde voorkoms van die kamer bepaal.

'n Konseptuele raamwerk, die evaluasie-responsmodel (ERM), wat deur Eagly en Chaiken (1993:10) voorgestel word, bied 'n praktiese benadering waarmee die betekenis van die gedekoreerde woonkamer bestudeer en geïnterpreteer kan word, omdat hierdie model ' $n$ responsbenadering is waarmee mense se houding bepaal kan word. Eagly en Chaiken (1993:4) stel voor dat die belangrikheid van die evaluasie-responsmodel op die werk van Osgood et al (1957:1) gegrond is. Osgood et al (1957:1) beweer dat 'n groot deel van die betekenis wat mense aan voorwerpe, plekke en ander entiteite toeken, evaluering behels. Daarom bou ERM op die feit dat evaluasie ' $n$ betekenisvolle rol speel in die wyse waarop mense sin maak van die ervaring van plekke en dus ook wat hulle ervaring van die gedekoreerde voorkoms van die woonkamer is. Die studie het ook ten doel om die ERM toe te pas op die gekonstrueerde omgewing, soos 'n woonkamer, om ' $n$ beter begrip te vorm van die houdingsprosesse.
Meeste van die tyd word die psigologiese betekenis van plekke deur middel van taalgebruik bestudeer. Clark en Clark (1977) is van mening dat dit moontlik is omdat taal betekenis kan kommunikeer. Die beste taalinstrument om sielkundige betekenis te bepaal, is die semantiese differensiaal (Emmerson \& Neeley, 1988). Hierdie instrument word gekenmerk deur 'n aantal bipolêre byvoeglike naamwoorde en woorde wat gebruik word om 'n besondere plek se voorkoms, soos die woonkamer, te beskryf, sowel as die gebruik van 'n intervalskaal waarop die beoordeling aangedui word. Die studie het dus ook ten doel om die gedekoreerde voorkoms van die woonkamer deur die toepassing van hierdie instrument te bepaal.

Van die loodstudie-onderhoude en die semantiesedifferensiaalstudies is 27 bipolêre byvoeglike naamwoorde as items geselekteer wat 'n verskeidenheid kwaliteite gemeet het, wat konseptueel verskillend was en wat die doeltreffendste was om die houding teenoor die voorkoms van die woonkamer te bepaal. 'n Sewepunt-evalueringskaal is gebruik en deelnemers is gevra om hul beoordeling van die woonkamer by elke item aan te dui deur 'n kruisie in die betrokke blokkie (gemerk 1-7) te maak.

'n Tweedimensionele (2D-) samestelling, met koëffisiënt 0.21904 , is uitgewys as die geskikste samestelling om die verband tussen die skaal en die houdingitems vir die gedekoreerde stikamers, wat op 'n subjektiewe beoordeling van die item berus, te bepaal. Die samestelling identifiseer drie hooftemas vir die betekenis van die gedekoreerde woonkamer: (1) 'n kerntema-area van betekenis, (2) 'n subtema-area van betekenis en (3) tema-omskrywers van betekenis. Die kerntema-area word voorgestel deur 'n sentrale area wat "ontspanne" houdingskenmerke insluit en die kwaliteit van gerief daarstel wat ervaar word deur na die gedekoreerde woonkamer te kyk.

Weens die verkennende aard van die studie is 'n doelgerigte geriefsteekproef van 53 vrywillige nuwe huiseienaars in Liverpool, wat eiendom binne 'n privaat ontwikkelde behuisingskompleks in die woonbuurte van West Derby of Croxteth in Brittanje besit het, en wat persoonlik die dekoratiewe veranderinge in die woonkamer aangebring het, gebruik. Die data is in die SPSS statistiese program ingelees en aan multidimensionele-skaalanalise en, meer spesifiek, kleinste-ruimteanalise onderwerp. Laasgenoemde is 'n nie-metriese multidimensionele skaalprosedure wat die verhouding tussen die houdingitems in geometriese ruimte en in die kleinste dimensionaliteit voorstel (Borg \& Shye, 1995:95). 
Die samestelling stel ook voor dat die woonkamer verteenwoordig word deur vyf subtema-areas van betekenis wat beskou kan word as bydraende komponente tot die kernkwaliteit van gerief. Hulle is: (a) Funksie, (b) Opgewondenheid, (c) Indrukwekkendheid, (d) Styl en (e) Kleur en Ruimte. Die subtemaareas word verkry deur die verband tussen die verskillende houdingitems van die onderliggende dimensies van betekenis wat met die gedekoreerde woonkamer geassosieer word, uit te druk.

Elke subarea bestaan uit een spesifieke houdingitem wat naby aan die kernkwaliteit van gerief binne die woonkamer geleë is. Hierdie houdingitems is ook hoogs korreleerbaar met betrekking tot die kwaliteit van gerief waarna verwys kan word as tema-indikators of -beskrywers van elke subtema. Die vyf temabeskrywers is: (a) "goed", in die Funksie-subarea, (b) "vriendelik", in die Opgewondenheid-subarea (c) "uitnodiging", in die Indrukwekkendheidsubarea, (d) "verwelkomend", in die Styl-subarea en (e) "positief", in die Kleur-en-Ruimte-subarea. Hierdie vyf temabeskrywers vang die hoof- en oorheersende ervaring binne die vyf subareas met betrekking tot die betekenis van gerief van die gedekoreerde woonkamer vas.

Daar word verder aan die hand gedoen dat die vyf omskrywers subjecktief gekombineer kan word in drie kwaliteitkomponente van gerief: (a) doel, wat die eienskappe van die Funksie-subarea uitbeeld sowel as die doel van die vertrek en wat daar gebeur, (b) atmosfeer, wat verteenwoordigend is van die subarea van Opgewondenheid wat die atmosfeer van die woonkamer uitbeeld en (c) voorkoms, wat in die Indrukwekkendheid, Styl, Kleur en Ruimte van die vertrek versinnebeeld word. Daarom kan gesê word dat die gerief van die woonkamer bepaal word deur die doel, atmosfeer en voorkoms van die woonkamer.

Die studie stel ook voor dat die drie komponente van gerief, (a) voorkoms, (b) atmosfeer en (c) doel gelykwaardig is aan die drie houding-responstipes van die ERM: (a) kognitiewe, (b) affektiewe en (c) gedragstipe response. Die kognitiewe komponent van die ERM behels die idees en denke oor die fisiese voorkoms van die vertrek, terwyl die affektiewe komponent meer spesifiek op die emosionele ervaring van die atmosfeer binne die vertrek dui; die gedragstipe respons verteenwoordig meer spesifiek die doel van die vertrek. Gebaseer hierop, word die ERM voorgestel as 'n konseptuele raamwerk waarbinne die houdingskonteks van die gedekoreerde woonkamer geplaas kan word.

Die studie het egter beperkinge, soos die feit dat menings slegs binne die gedekoreerde woonkamer van die behuisingsomgewing verkry is, wat nie voorsiening maak vir die veralgemening daarvan na ander vertrekke in die woonhuis nie. Die studie is ook spesifiek op 'n woonbuurt in Brittanje van toepassing, en Suid-Afrikaanse huiseienaars sal moontlik nie dieselfde mening as Britse huiseienaars huldig nie. Studies oor die betekenis van hier- die vertrek met betrekking tot die gedekoreerde voorkoms daarvan kan gedoen word om die verskille en ooreenkomste in menings tussen verskillende lande uit te wys, en dit kan bydra tot ' $n$ universele begrip van die voorkoms van so 'n vertrek.

\section{- Dr EL Kempen}

Department of Life and Consumer Sciences UNISA

\section{Introduction}

People's experience of places, such as their own personal living room that they have modified and decorated as a first-time homeowner in a newly built house, has not been explored in terms of the sense they make of it and therefore of the meaning of this room. In general the British living room is considered the hub of the contemporary British home (GiraltMiracle, 1975:65), afforded with a multipurpose quality that also supports personal, social and cultural activities of the home (Nissen et al, 1994:206). The underlying assumption is that, apart from the contemporary purpose, the present British living room in new housing developments has a particular meaning to its occupants, which is achieved through its decorated appearance, the subsequent atmosphere resulting from the interior decoration and the present-day activities that take place in this room. Little (1987:205) suggests that a place achieves meaning through the experience it creates within its observer, which is either attractive or repulsive, resulting in a personal sense of place in the particular built environment, whether it be a room, office, store or any other built space (Choker, 1993:293).

One way to determine place meanings of built spaces, such as the personal living room, is to study people's attitudes (Eagly \& Chaiken, 1993:1; Olson \& Zanna, 1993; Hanyu, 1997; Lyons, 1998:341), as attitudes can reveal the underlying dimensions that place experiences offer. According to Canter and Thorne (1972), people's attitudes are particularly sensitive psychological processes with which to determine the meanings of places. Studies conducted by Canter (1970), Canter and Wools (1970), Canter and Thorne (1972) and Devlin and Nasar (1989) have showed how the meaning of places (i.e. room interiors or types of houses) can be assessed through the judgements people make of the appearances of places they have been introduced to. Therefore, newly modified personal living rooms may also hold particular meanings that could be captured through the appearance the room takes on.

The appearance of the contemporary British living room receives a lot of decorating attention and is frequently changed through modification (Caborn, 2001). The modified appearance of the living room, or interior style, can in effect be used as a stimulus with 
which to determine peoples' attitude towards the room and therefore the meaning this room attains.

\section{THEORETICAL BACKGROUND}

A conceptual framework provided by the evaluative response model (ERM) proposed by Eagly and Chaiken (1993:10) offers a practical approach by which to study and interpret the meaning of the interior style of the contemporary living room (CLR), as it is a response approach through which to study people's attitudes. Eagly and Chaiken (1993:4) argue the importance of their evaluative response model from the work of Osgood et al (1957:1), who proposed that a large proportion of the meaning people assigned to objects, places and other entities was evaluative in nature. Therefore, the evaluative response model draws from the fact that evaluation plays a significant role in how people make sense of what they experience in places.

To exemplify this, Figure 1 illustrates that the responses to the attitude object reveal the existence of an attitude that is expressed through evaluation. The response approach is based on the notion that the ERM presumes that an attitude is an intervener between the attitude object, and the response to the attitude object (Homer \& Kahle, 1988). An attitude object can be defined as any tangible item presented to a person to determine their opinion of the item and thus their attitude towards the item (e.g. interior style). ERM assumes that the intervening attitude accounts for the degree to which the observable response is in accord with the observable attitude object for an attitude to be able to exist. Thus, people's understanding of the meaning of the interior style of the decorated living room can be revealed through the attitude they hold towards the appearance of the living room.

\section{Defining an attitude within ERM}

Based on the abovementioned assumptions, some concepts have to be clarified. According to Eagly and Chaiken (1993:1) the perspectives, ideas and opinions people have of an object form the attitude they have towards the particular attitude object. Eagly and Chaiken (1993:2) and Oppenheim (1999:175) suggest that these attitudes are in fact latent, hidden or dormant processes that exist in people's minds and can be expressed only when the attitude object is perceived. In addition to this definition, Olson and Zanna (1993) consider an attitude in terms of three main assumptions: (a) an attitude is an evaluation which can be overt or covert, cognitive, affective or behavioural; (b) an attitude is represented in memory and characterised as a knowledge structure and as an associative network of interconnected evaluations and beliefs; and (c) attitudes are characteristic of affective, cognitive and behaviour antecedents that can be distinguished as affective, cognitive and behavioural consequences.

Eagly and Chaiken (1993:2) use these three broad assumptions of Olson and Zanna (1993) to produce a definition by means of which to explore people's perspectives towards an attitude object. They propose that "Attitude is a psychological tendency that is expressed by evaluating a particular entity with some degree of favour or disfavour." This definition identifies two main components of an attitude that form the essence of the ERM: an attitude (1) identifies qualities within the person that act as influential sources, also referred to as psychological tendencies that are reflective of why or how a person might react to the attitude object; and (2) an attitude develops on the basis of an evaluative response to the attitude object (i.e. expressing approval or disapproval, liking or disliking).

\section{Evaluative response types}

Eagly and Chaiken (1993:10) identify three response types that form the cornerstone of the ERM. These

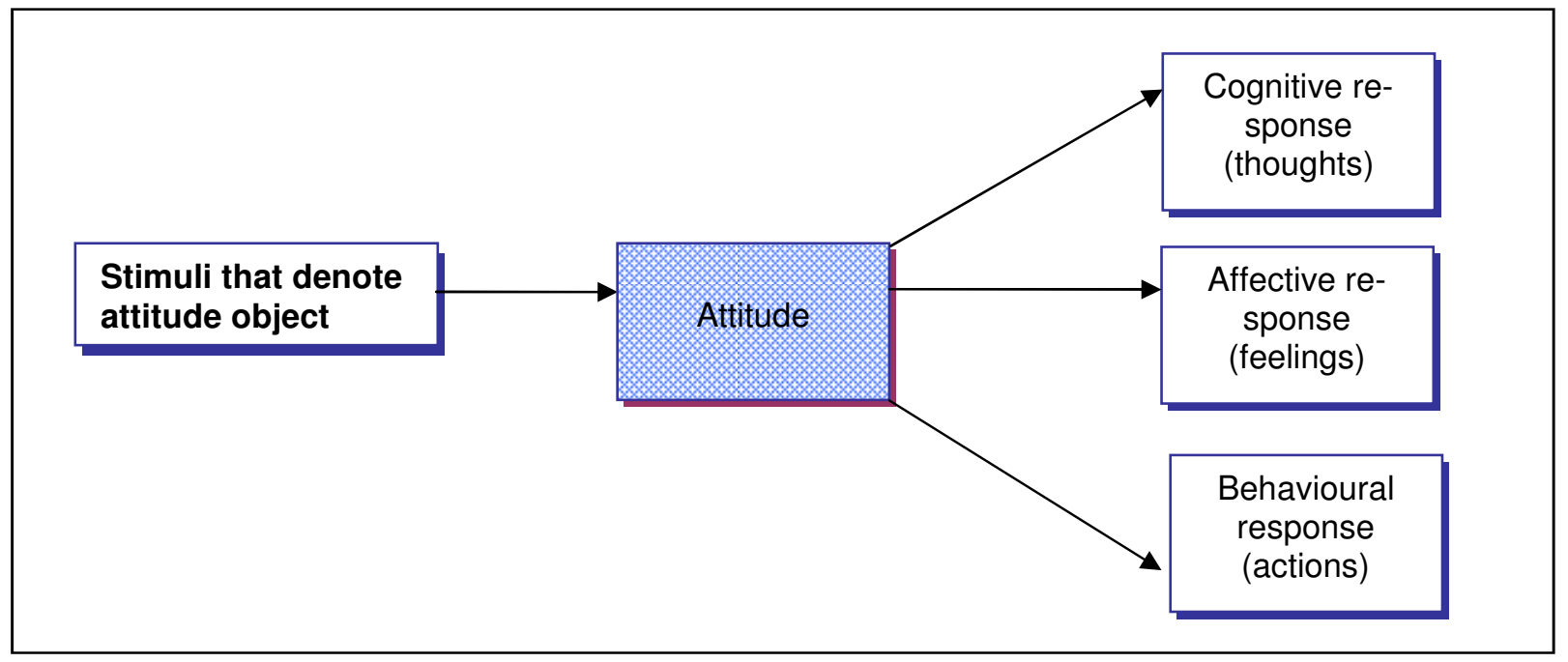

FIGURE 1 EAGLY AND CHAIKEN'S MODEL OF AN ATTITUDE AS AN INFERRED SATE, WITH EVALUATIVE RESPONSES DIVIDED INTO COGNITIVE, AFFECTIVE AND BEHAVIOURAL CLASS TYPES (Eagly and Caiken, 1993:10) 
response types are (a) cognitive, (b) affective and (c) behavioural. These three main response types are similar to the tripartite model of attitudes and also referred to as the structural approach to attitudes (Lyons, 1998:340). Eagly and Chaiken (1993:10) suggest that each one of these response types can be defined as follows.

\section{Cognitive responses}

Eagly and Chaiken (1993:11) suggest that cognitive response reflects the thoughts and ideas people have about the attitude object, which are often conceptualised as beliefs but more often referred to as knowledge, opinions, information and inferences about an attitude object. These conceptualisations form the links between the attitude object and the various attributes of the attitude objects. Therefore, favourable evaluations are likely to be linked with positive attributes. Both positive and negative beliefs about the attitude objects may be shared.

\begin{abstract}
Affective responses Affective response refers to emotions, feelings and moods that are experienced with regard to the evaluation of the attitude object and are thus a way of responding to the attitude object (Eagly \& Chaiken, 1993:11). Eagly and Chaiken (1993:11) state that people who evaluate an attitude object favourably are generally also likely to experience a positive affective reaction, contrary to what others might experience, which may range from extremely positive experiences to extremely negative experiences.
\end{abstract}

\section{Behavioural responses Behavioural response} refers to the intentions to act or to the overt action associated with the attitude objects. People who evaluate an attitude object favourably tend to engage in behaviours that support such an attitude, while others might resort to opposite behaviour (Eagly \& Chaiken, 1993:12). Thus, a person who dislikes the living room because of its design, location and layout might never decorate or personalise the room, whereas others may like the living room and modify it to represent this favourable state.

The fact that the ERM assumes that an attitude is already present, of which the response is the outcome, offers an opportunity to use this assumption to determine what attitude can be revealed towards the decorated appearance of living rooms. The aim of this study is therefore to measure new homeowners' attitudes towards the decorative appearance of the living room they have decorated in their new home, and to determine the meaning that this newly decorated living room has through the decorative appearance the living room has taken on.

\section{METHODOLOGY}

The method of extracting meaning through attitudes challenges the traditional methods of determining meaning. Most often the psychological meaning of places has been explored through the use of everyday language, as language best communicates meaning
(Clark \& Clark, 1977:3). Authors who have successfully used language, in the form of a semantic differential (SD), to extract place meaning include Wools (1969:23), Canter (1970), Canter and Wools (1970), Acking (1971:46), Honikman (1971:24), Canter and Thorne (1972), Hall et al (1976), Mercer et al (1980), Russell et al (1981), Marans and Speckelmeyer (1982), Pedersen (1986), Devlin and Nasar (1989), Ornstein (1992) and Ritterfeld and Cupchik (1996). The semantic differential is considered one of the best -known language instruments with which psychological meaning has been explored (Szalay \& Deese, 1978:4; Emmerson \& Neeley, 1988), although it has not lately been applied to determine place meaning.

Osgood et al (1957:1) have postulated that the SD instrument relies on three fundamental dimensions through which meaning from natural languages can be retrieved: (a) "potency", (b) "evaluation" and (c) "activity". However, in this instance the SD instrument had not been applied to extract the meaning of physical settings (Bechtel, 1975:43; Russell et al, 1981; Hanyu, 1997), although these dimensions seem to dominate the field of place research (Ward \& Russell, 1981). Although Oppenheim (1992:236) is of the opinion that the SD is a subjective measure of meaning and therefore a suitable instrument to apply to the field of place research, Canter and Wools (1970) have illustrated the robustness with which SD had been used in studies to determine the meaning of places such as rooms. In this instance they extracted three different dimensions of place meaning that rooms consisted of, namely (a) character, (b) harmony and (c) friendliness.

Nonetheless, Canter (1969) was among the first researchers to question whether the three dimensions proposed by Osgood et al (1957:32) would also relate to architectural forms. Canter found little evidence to this effect but rather proposed "character", "coherence", "friendliness" and "activity", with various subsidiary dimensions that best captured the meaning of architectural places. Canter (1969) and Hanya (1997) have also suggested that the semantic dimensions Osgood et al had developed needed to be used with great care where architectural forms were concerned and not be generalised to all built environments.

To augment the meaning of built environments, Horayangkura (1978) has held that "evaluation", "urbanisation" and "organisation" emerge distinctly as fundamental dimensions people perceive in the meaning of residential environments. Contrary to the perspectives of Canter (1969) and Horayangkura (1978), Mehrabian and Russell (1974) have instead proposed "pleasure", "arousal" and "dominance" as the three dimensions that exemplify the meaning of the physical environment. According to Russell et al (1981), these dimensions correspond better to the interpretations of the physical environment than Osgood et als dimensions. Although many different meanings have been attributed to the physical environment, there does not seem to be one single coherent meaning (Russell et al, 1981). However, there is evidence that the SD instrument is able to extract the place meanings from 
the built environment and may therefore be helpful in revealing the meaning that a personally decorated living room may have. The aim of the study is therefore also to explore the use of the semantic differential measuring instrument to determine the meaning of the living room as perceived through its appearance.

\section{Characteristics of the semantic differential instrument}

The SD instrument, which is a comprehensive measuring instrument, has two characteristic constituents: Firstly, it uses a number of bipolar adjectives, which are words people use to describe or talk about places. In this respect, Kasmar (1970) has presented a meaningful lexicon of architectural descriptors or words used to describe architectural spaces, which were consulted for this study. The descriptors are used to form bipolar adjective (opposite) scales. These scales are then used to evaluate places (Hall et al, 1976; Oppenheim, 1992:236). For example, a bipolar adjective scale may include such descriptive adjectives as "unpleasant" vs "pleasant" or "uncomfortable" vs "comfortable", which also give an indication of the direction of the evaluation.

Secondly, the bipolar adjective scales are rated along an interval rating scale, as the numbers used in the scale are also an equal distance apart (Hayes, $2000: 242$ ). The purpose of the rating scale is to provide information on the strength of the evaluation, captured in the score assigned to each of the bipolar adjective scales. A seven-point rating scale is therefore used to evaluate the appearance of a room, where 1 is the least favourable state (i.e. dark and airless) and 7 the most favourable state (i.e. light and airy).

However, several authors debate the number of intervals used between the adjective items. Heis (1969) and Oppenheim (1992:236) point out that seven-point scales are customary when an SD instrument is used to evaluate places and objects. Heis and Oppenheim argue that this is based on the argument that not more than seven discriminations can be made simultaneously. Contrary to this, Horayangkura (1978) uses an 11 -point scale, arguing that a greater number of categories allow better discrimination between the stimuli to be judged, especially those that are rather homogeneous. Nonetheless, Wools (1969:23), Canter and Wools (1970) and Canter and Thorne (1972) have successfully used seven-point rating scales in their explorations of people's evaluations of buildings.

The studies by Canter and others never question the number of rating points or consider any comparative analysis of the use of different rating points when using the SD instrument during studies on building evaluation. However, their studies have been able to reveal the meanings that buildings had by using seven -point rating scales. The significance of the SD instrument is found in its ability to identify which particular aspect of a stimulus subjects perceive and respond to by drawing out the important dimensions people perceive when they evaluate or judge a particular place or object given to them (Hall et al, 1976).

\section{Item selection for semantic differential (SD)}

Canter and Wools (1970) have proposed that when the SD instrument is applied to places such as rooms or buildings, SD should be representative of the language people would use to talk about these places in an evaluative context. Therefore, in order to create an SD instrument that would measure the attitude of people towards their own personally decorated living room, it would be necessary to become familiar with the language people would use to describe the decorated living room. Two sources of descriptive language were used in order to compile the SD instrument for this study: (a) pilot interviews that were conducted with new homeowners in Liverpool prior to the main study, which led to a list of verbal descriptions given of their experiences of the living rooms they had modified and decorated after moving in; and (b) other place studies by Canter (1970), Kasmar (1970), Honikman (1971:26), Canter and Thorne (1972), Mercer et al (1980), Russell et al (1981), Pedersen (1986), Ornstein (1992) and Ritterfeld and Cupchik (1996), which have used a semantic differential scale to measure aspects of the built environment.

From the descriptive sources (i.e. pilot interviews and SD studies), 27 bipolar adjective items, as presented in Table 1, were selected that measured a variety of qualities particular to the interior design field, but were conceptually different from each other, which would compel the participant to judge each item accordingly and would best capture the attitude towards the appearance of the living room. Apart from the conceptually dissimilar items, the majority of items were found to be similar to verbal associations that the study sample of new homeowners made of their own living rooms. This offered a form of validity to the SD instrument. Therefore, by rating these popular verbal associations, it was possible to determine the strength of the verbal descriptions of the living room and how they related to each other.

Based on previous discussions, a seven-point rating scale was used to assess the 27 attitude items. Apart from being the most frequently used scale with which to rate SD items, it was felt that the seven-point scale would be less strenuous and confusing to complete. Consideration was given to the difficulty of the instrument, especially where participants were unfamiliar with the use of SD instruments. Increasing the difficulty of the SD instrument could result in an instrument that would not measure the meaning of the living room, because of the difficulty of comprehending the words used in the scales and the difficulty of completing the instrument. Participants were given the instruction: "Please indicate where the living room comes on each of the scales below by putting the appropriate number (1-7) in the box provided."

Due to the explorative nature of the study, it used a purposive convenience sample of 53 voluntary new homeowners in Liverpool who had moved into new homes on privately developed estates in the West Derby and Croxteth wards and who had personally completed decoration and modification to the new 
TABLE 1:

SEMANTIC DIFFERENTIAL ATTITUDE ITEMS USED TO RATE THE APPEARANCE OF THE LIVING ROOM

\begin{tabular}{|c|c|c|c|c|c|c|c|c|}
\hline \multicolumn{9}{|c|}{27 ATTITUDE ITEMS } \\
\hline inadequate & 1 & 2 & 3 & 4 & 5 & 6 & 7 & adequate \\
\hline unsuitable & 1 & 2 & 3 & 4 & 5 & 6 & 7 & suitable \\
\hline unacceptable & 1 & 2 & 3 & 4 & 5 & 6 & 7 & acceptable \\
\hline unpleasant & 1 & 2 & 3 & 4 & 5 & 6 & 7 & pleasant \\
\hline uncomfortable & 1 & 2 & 3 & 4 & 5 & 6 & 7 & comfortable \\
\hline bad & 1 & 2 & 3 & 4 & 5 & 6 & 7 & good \\
\hline uninteresting & 1 & 2 & 3 & 4 & 5 & 6 & 7 & interesting \\
\hline depressing & 1 & 2 & 3 & 4 & 5 & 6 & 7 & stimulating \\
\hline worst possible & 1 & 2 & 3 & 4 & 5 & 6 & 7 & best possible \\
\hline below average & 1 & 2 & 3 & 4 & 5 & 6 & 7 & above average \\
\hline inconvenient & 1 & 2 & 3 & 4 & 5 & 6 & 7 & convenient \\
\hline cramped & 1 & 2 & 3 & 4 & 5 & 6 & 7 & spacious \\
\hline chaotic & 1 & 2 & 3 & 4 & 5 & 6 & 7 & orderly \\
\hline unfriendly & 1 & 2 & 3 & 4 & 5 & 6 & 7 & friendly \\
\hline uninviting & 1 & 2 & 3 & 4 & 5 & 6 & 7 & inviting \\
\hline dark and airless & 1 & 2 & 3 & 4 & 5 & 6 & 7 & light and airy \\
\hline drab & 1 & 2 & 3 & 4 & 5 & 6 & 7 & bright \\
\hline stale and dusty & 1 & 2 & 3 & 4 & 5 & 6 & 7 & fresh and clean \\
\hline out dated & 1 & 2 & 3 & 4 & 5 & 6 & 7 & fashionable \\
\hline tense & 1 & 2 & 3 & 4 & 5 & 6 & 7 & relaxed \\
\hline ugly & 1 & 2 & 3 & 4 & 5 & 6 & 7 & beautiful \\
\hline negative & 1 & 2 & 3 & 4 & 5 & 6 & 7 & positive \\
\hline impersonal & 1 & 2 & 3 & 4 & 5 & 6 & 7 & personal \\
\hline unwelcoming & 1 & 2 & 3 & 4 & 5 & 6 & 7 & welcoming \\
\hline unimpressive & 1 & 2 & 3 & 4 & 5 & 6 & 7 & impressive \\
\hline unsophisticated & 1 & 2 & 3 & 4 & 5 & 6 & 7 & sophisticated \\
\hline poor & 1 & 2 & 3 & 4 & 5 & 6 & 7 & excellent \\
\hline
\end{tabular}

living room. A homogenous group of new homeowners were thus targeted, as the homes they move into are often a bare shell that may in some cases not include flooring, lighting, curtain rails or a fireplace but only walls painted with the standard magnolia paint that contractors use.

\section{Data analyses}

The response ratings for 49 living rooms on 27 attitude items were entered into the SPSS statistical program. Wilson and Canter (1990) have shown that a sample size of $15-20$ participants is sufficient to produce a stable structure for Multidimensional Scalogram Analysis (MDS). The attitude items formed the columns of the data matrix, and the rows represented the respondents' personal ratings for each bipolar adjective attitude item.

Multidimensional scaling analysis of the meaning of living rooms Emmerson and Neeley (1988) note that as meaning is commonly assumed to be subjective in nature and does not lend itself to quantitative analysis, the SD allows the researcher to obtain quantitative scores, which can then be subjected to various analytical procedures. By using a rating scale within the SD instrument, quantitative analytical procedures such as multivariate analysis, of which factor analysis
(Hall et al, 1976) or, more favourably, multidimensional scaling (Russell et al, 1981) can be used to extract the "underlying structure" or meaning within the ratings on each of the attitude items. This is based on the fact that the complex relationship between these attitude items can be explored (Grimm \& Yarnold, 1995:3).

However, Gärling (1976) is of the opinion that multidimensional scaling on ratings, such as the SD offers, best represents an evaluative assessment of the similarities of the physical environment, to which the individual contributes his/her knowledge of the place. Multidimensional scaling is for that reason one approach that Ward and Russell (1981) have identified to extract place meaning. These authors also suggest that multidimensional scaling is fundamental in determining the relationship between places (i.e. living rooms). It is therefore suggested that multidimensional scaling may also be helpful in determining the relationship of elements within a place (i.e. excitement and light). Furthermore, this method is thus able to determine the relationship between the physical appearance of a place (i.e. living room) and the psychological process such as the attitudes of the occupants.

The data entered into the SPSS program were subjected to a multidimensional scaling procedure, namely smallest space analysis (SSA). SSA is a non- 
metric multidimensional scaling procedure that represents the association between the attitude items in geometric space and in the smallest dimensionality (Borg \& Shye, 1995:97) which allows for a rigorous multivariate analysis under the constraints of no special assumptions (Bloombaum, 1970). This association identifies similarities and differences (Borg \& Groenen, 1997:3) between the 27 attitude items, which is achieved through the SSA program's ability to compute correlation coefficients between all the attitude items. In so doing, an association matrix of every attitude item with every other attitude item is created. In this instance the association matrix is characteristic of the fact that the higher the association between any pair of attitude items, the higher the correlation would be between these items (Brown \& Barnett, 2000:105). Correlation coefficients were calculated using Pearson's product moment correlation coefficient.

A further transformation of the data takes place in that the patterns of correlations are converted to linear distances. As a result, the higher the association is between any pair of attitude items, the shorter the distance between them is (Stalans, 1995:137; Brown \& Barnett, 2000:106). Consequently, the further apart two attitude items are, the lower the association between these attitude items would be in geometric space (Borg \& Groenen, 1997:5).
Furthermore, in an attempt to find an optimal representation of the attitude items, SSA performs iterations that compare the rank order assigned to the original associations with the rank order of the distances between points in the plot (Brown \& Barnett, $2000: 106)$. With each iteration, adjustments are made to the geometric representation in an attempt to minimise the difference between the plot and the original association matrix. The closer the two sets of rank orders, the better the fit. These iterations continue until the difference between these two matrixes is at a minimum. The degree of fit between the geometric representation and the original data is indicated by a coefficient of alienation (Brown \& Barnett, 2000:106). The coefficient of alienation ranges from 0 (i.e. indicating a perfect fit) to 1 (i.e. indicating the worst fit). A coefficient below 0.20 or 0.25 is often considered a reasonably good degree of fit. Shye et al (1994:27) are of the opinion that determining how good or bad the coefficient is depends on a number of factors, such as the number of variables being analysed. Moreover, Canter and Donald (1990) propose an acceptable level of fit between 0.15 and 0.2. Canter and Donald suggest that the essential criterion for acceptability of the "goodness of fit" indication depends most often on the interpretability of the solution.

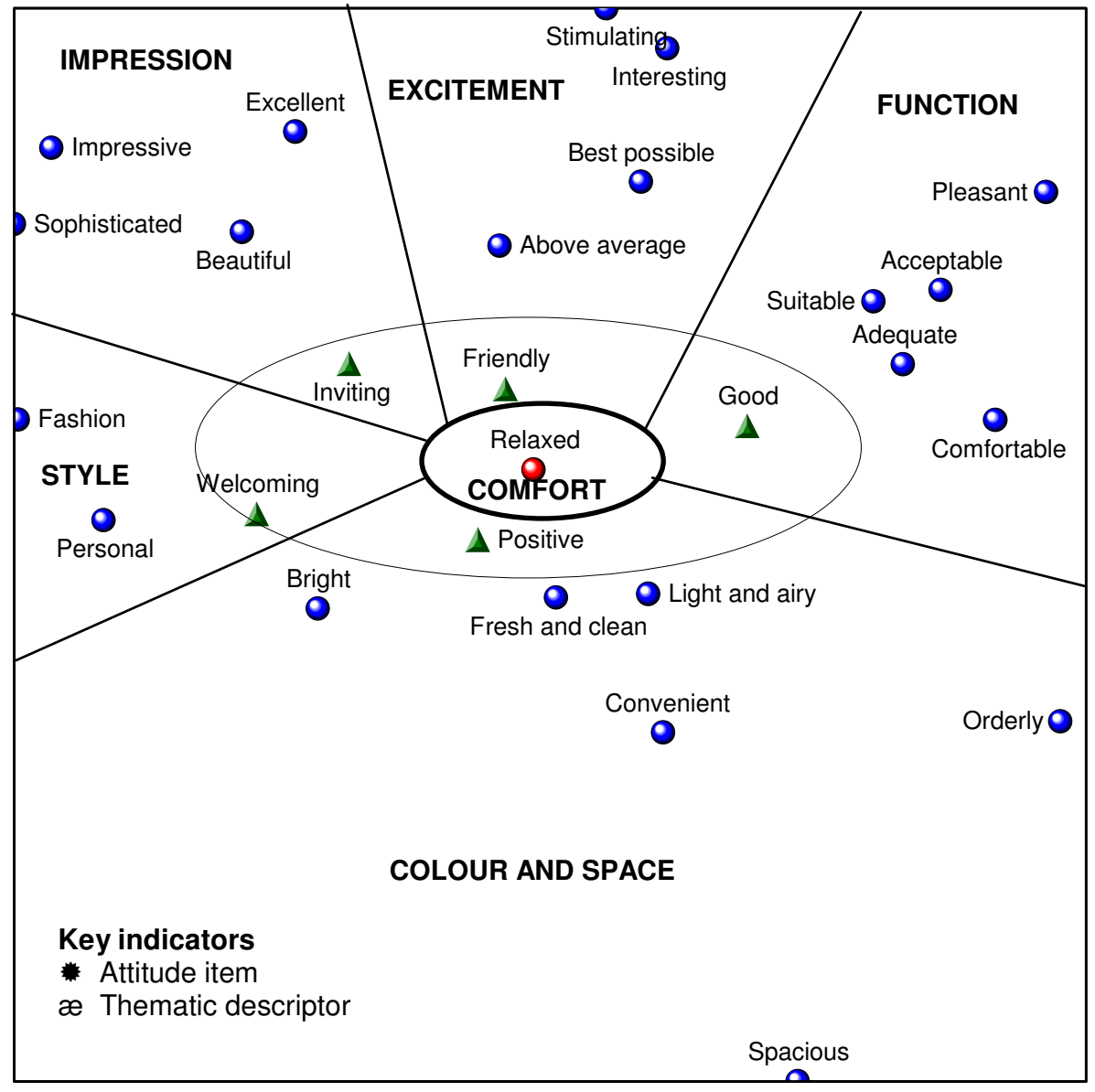

FIGURE 2: SSA OF ATTITUDE RATINGS OF THE APPEARANCE OF THE MODIFIED LIVING ROOM WITH COEFFICIENT OF ALIENATION 0.21904; 2D 
The configurations resulting from the SSA procedure present a visual picture of the variables as points in space (Stalans, 1995:137). This is based on the relationship between the various attitude items. Consequently, the relationship between the attitude items in geometric space makes it possible to partition the space when the regional contiguity patterns are interpreted (Shye et al, 1994:19; Borg \& Shye, 1995:10). These points can be examined directly without assuming underlying dimensions. Configurations such as these develop from the relationship between items and not the axis, as these are arbitrary. Canter and Heritage (1990) state that the relationships between the variables are replicably determined. One advantage of the resulting configurations is the fact that they offer the researcher the opportunity to literally look at the results and to explore the configurations and structure (Borg \& Groenen, 1997:68). Therefore, attitude items that represent a particular meaning of the decorated living room would be within a similar region. Stalans (1995:137) is of the opinion that such meaningful regions form the underlying structure or dimensions of the data based on the association between the various attitude items used in the analysis.

\section{RESULTS AND INTERPRETATION}

Figure 2 is a two-dimensional (2D) configuration that is an indication of the number of coordinated axes in the configuration (Schiffman et al, 1981:54) with coefficient of alienation 0.21904 . This configuration was found useful to represent the relationship between the ratings on the attitude items for the decorated living room, based upon a subjective judgment of the items. According to Szalay and Deese (1978:62), this judgement involves a salient process of perception and evaluation by the respondents.

The configuration reveals three main thematic regions that represent the meaning of the decorated living room: (1) a core thematic region of meaning, (2) subthematic regions of meaning and (3) thematic descriptors of meaning. This was achieved by using the configuration depicted in Figure 2 where after the researcher subjectively divided the space into regions based on the way in which the attitude items related to each other in a meaningful way. A subjective name was then given to the region of grouped attitude items. Any further interpretation of the plot was also reflective of additional meaning that was extracted from the configuration.

\section{Core thematic region of meaning of the decorated living room}

Based on the subjective interpretation of the plot it is suggested that in Figure 2, the core thematic region is configured around a centre region that includes the "relaxed" attitude item. This item forms a core region that represents a quality of comfort experienced within the decorated living room. This core component results from a strong relationship with each of the other attitude items in semantic space. The core component is, therefore, a central and fundamental quality of the living room, around which other thematic regions of meaning revolve.

\section{Sub-thematic regions of meaning of the decorated living room}

Further interpretation of the plot suggests that the living room is representative of five thematic subregions that can be viewed as components contributing to the core quality of comfort. The five thematic sub-regions are: (a) Function, (b) Excitement, (c) Impression, (d) Style and (e) Colour and Space. The thematic sub-regions are derived from the relationship between different attitude items, forming clusters of attitude items that capture the underlying meaningful dimensions associated with the decorated living room and subjectively named by the researcher.

Function sub-region The first thematic sub-region is labelled Function, located in the top right corner of the plot, and it consists of items describing the functional and purposeful quality of the living room. Attitude items such as "pleasant", "acceptable", "suitable", "adequate" "good" and "comfortable" represent the functional sub-region and are an indication that the purpose, use and function of the living room are also dimensions of comfort associated with the decorated living room.

Excitement sub-region The second thematic subregion is labelled Excitement, located in the top middle of the plot, and it is characterised by attitude items describing the perceived intensity of the living room, such as "stimulating", "interesting", "best possible", "friendly" and "above average". These are attitude items also contributing towards the comfort of the living room. However, the attitude items within this sub-region are characteristic of the atmosphere experienced in the living room and therefore capture affective and emotional experiences associated with the living room.

Impression sub-region The third thematic subregion is labelled Impression, located in the top left corner of the plot, and it includes attitude items such as "impressive", "excellent", "sophisticated", "inviting" and "beautiful", describing the impact the living room makes upon its observers and suggesting that the relationship between these attitude items indicates the impression of attractiveness created by the living room. The impression of the living room is a further effect of the atmosphere that contributes to the comfort and is also characteristic of affective experiences associated with the decorated living room.

Style sub-region The fourth thematic sub-region is labelled Style. The attitude items "fashionable", "personal" and "welcoming" represent this sub-region, to the left of the plot. This region is an indication that the style of the living room resembles fashionable trends in furnishing and décor. The relationship between the attitude items suggests that the appearance of the living room also resembles a style that has been put together with personal touches and ideas of the new homeowner. This may result in a 
personal style and identity being created in the living room, which may also be different from that of other living rooms but is an appreciated quality that contributes to the comfort of the living room and is mainly characteristic of its physical appearance.

Colour and space sub-region The fifth thematic sub-region is labelled Colour and Space, located at the bottom of the plot, and it is representative of attitude items describing the qualities of colour and space of the living room. Colour within the living room includes attitude items such as "bright", "fresh and clean" and "light and airy", whereas space consists of attitude items such as "convenient", "spacious" and "order". The attitude items that form this region are positive experiences of the colour and spatial qualities of the living room, as found in the "positive" attitude items established in this region, which contribute to the perceived quality of comfort of the living room but also represent the physical appearance of the decorated living room.

\section{Thematic descriptors of meaning of the decorated living room}

A further subjective interpretation of the configuration in Figure 2 suggests that each sub-region consists of one attitude item that is in close proximity to the core quality of comfort within the living room. These attitude items are also highly correlated with the core quality of the component, resulting in the close relationship to the core component, and referred to as a thematic indicator or descriptor of each thematic subregion. The five thematic descriptors are: (a) "good" in the Function sub-region, (b) "friendly" in the Excitement sub-region, (c) "inviting" in the Impression subregion, (d) "welcoming" in the Style sub-region and (e) "positive" in the Colour and Space sub-region. These five thematic descriptors capture the main and overall experience of the five sub-regions with regard to the meaning of the comfort of the decorated living room. It is, therefore, possible to summarise the qualities of the sub-regions with the use of the comfort descriptors to mean that the function of the living room is "good", the level of excitement in the living room is "friendly", the impression of the living room is "inviting", the style of the living room is "welcoming" and the colour and space of the living room are "positive".

The subjective interpretation of the regions also suggests that the five descriptors can be combined into three quality components of comfort, which are (a) purpose, (b) atmosphere and (c) appearance. For example, the Function sub-region is characteristic of the purpose of the room and what happens there, whereas the sub-regions of Excitement best represent the atmosphere of the living room and that the subregions Impression, Style, Colour and Space are indicative of the appearance of the living room. Therefore, it is suggested that the comfort of the living room is captured within the purpose, atmosphere and appearance of the living room.

\section{Application of the ERM}

Figure 3 is a model of the application of the ERM to the general attitudes towards the appearance of the decorated living room whereby the three comfort components (a) the appearance, (b) the atmosphere and (c) the purpose) are equated with the three response types from the ERM of attitudes, which are (a) cognitive, (b) affective and (c) behavioural responses. The argument for such an application is based on the following.

Cognitive response to the living room Firstly, in the light of the fact that the cognitive response of an attitude represents the ideas and opinions about an attitude object, it can be suggested that the attitude towards the decorated living room brings about an understanding of its physical qualities. These physical qualities are found in the appearance of the living room as captured in the Style and in the Colour and Space sub-regions.

Affective response to the living room Secondly, the affective response of an attitude consists of emotions attributed to the specific object. For example, the emotional assessment of the decorated living room can be found in the Impression and Excitement subregions, which represent the experience of the atmosphere within the living room, found in its easy accessibility and its happy and pleasurable quality.

Behavioural response to the living room Thirdly, the behavioural response of an attitude consists of action responses. In this respect, the functional subregion represents an evaluation of the purpose and use of the living room and its related activities, which in this case is satisfactory. For example, when in use the living room is "comfortable", "adequate", "suitable", "acceptable" and "pleasant". Although these variables are not direct indications of any purposeful activities associated with the living room, they represent items with which activities in general are evaluated.

\section{CONCLUSION}

The study is evidence of the fact that attitudes are valuable psychological processes which are able to reflect the meaning that a place such as a decorated living room may have and therefore particularly the sense that people make of the appearance of such a place. In this respect, the study has shown that the appearance a place takes on is a meaningful source of information that can be analysed in such a way that a clear subjective understanding is formed of the dimensions on which the meaning of the decorated living room or place is built. It is especially within the Consumer Science discipline and its specialisation in interior design that these findings become significant as interior design needs to understand and consider the meaning places have when recommendations are made and appearances of environments are changed.

The use of the SD instrument has proved that language is still a fruitful way of determining the meaning of places. Moreover, the study has proven that the semantic meaning of the appearance of the modified 


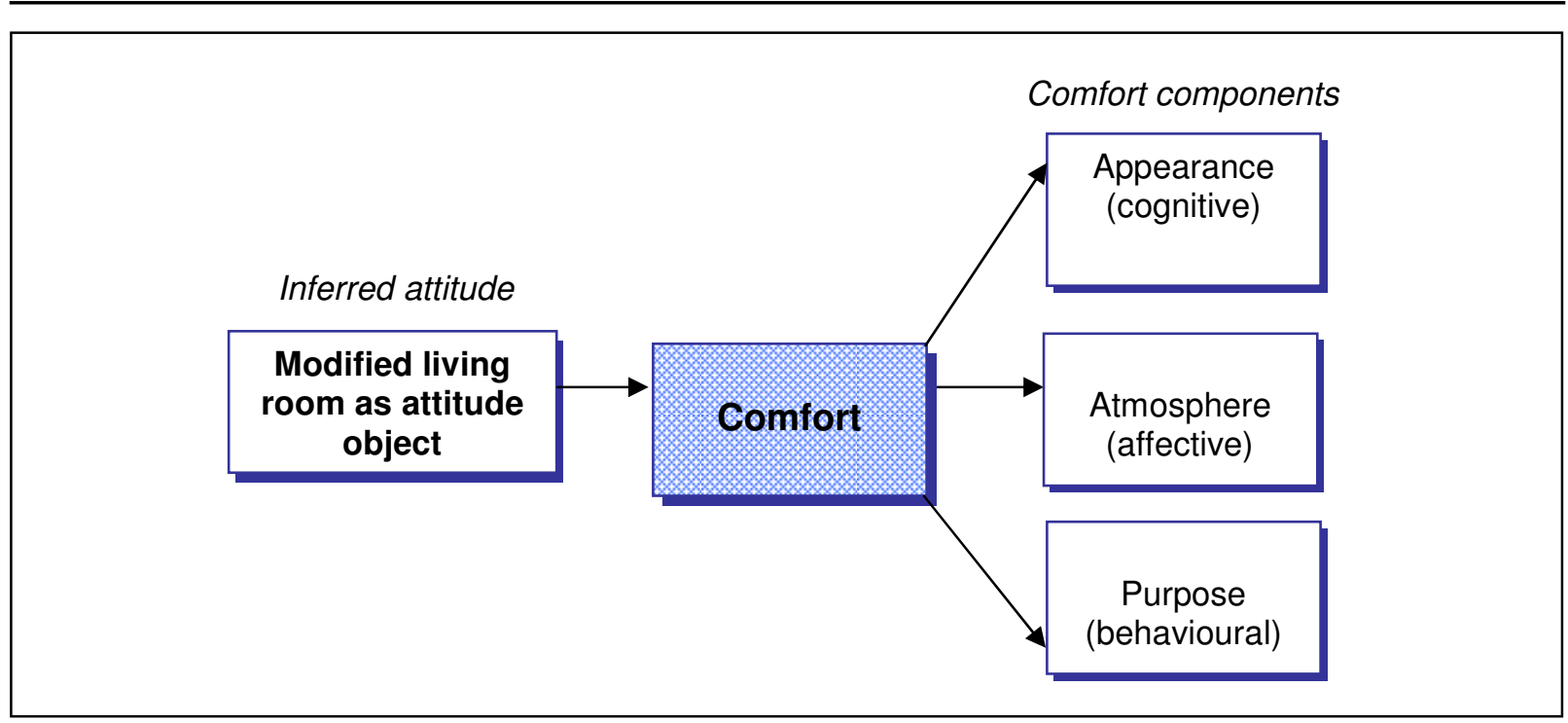

FIGURE 3: AMENDED VERSION OF EAGLY AND CHAIKEN'S ERM MODEL OF AN ATTITUDE AS AN INFERRED STATE OF THE THREE COMFORT AND PLACE COMPONENTS OF THE LIVING ROOM (Eagly and Chaiken, 1993:10)

and decorated living room is theorised around a core quality of comfort, which includes the appearance, atmosphere and purpose of the room. "Comfort" is thus not a singular term with which to describe the room but is rather an umbrella term which includes other subjective dimensions that make up the element of comfort.

ERM as an interpretive conceptual framework was successful in capturing the theoretical meaning of the appearance of the decorated living room. The three response types were also useful in interpreting the meaning that the decorated appearance of the living room takes on. In the light of the fact that the ERM has not been applied to the built environment, the study has shown how the ERM can be applied to a broader research field.

However, the study sought meaning within the living room of the housing environment, which does not allow for generalisation to other rooms in the home. It is therefore suggested that the study be conducted within other rooms in the home in order to find the meaning they may have and to identify the differences between the meanings. The study was also limited to determining meaning through the decorative appearance although meaning can be derived from various other elements associated with rooms. Furthermore, this study was conducted within a British housing context. The meanings that a decorated living room within a South African context have should also be explored to find the similarities or differences that may exist in meaning. This would allow for a universal understanding of such a room.

\section{REFERENCES}

ACKING, CA. 1971. Factorial analysis of the perception of an interiorln Honikman, B. (Ed) 1971. Proceed- ings of the architectural psychology conference at Kingston Polytechnic. London. RIBA Publications.

BECHTEL, RB. 1975. The semantic differential and other paper-and-pencil tests. In Michelson, W. (Ed) 1975. Behavioural research methods in environmental design. Stroudsburg, Pennsylvania. Dowden, Hutchinson \& Ross.

BLOOMBAUM, M. 1970. Doing smallest space analysis. The Journal of Conflict Resolution 14(3): 409-41. BORG, I \& GROENEN, P. 1997. Modern multidimensional scaling: Theory and applications. New York. Springer.

BORG, I \& SHYE, S. 1995. Facet theory: Form and content. London. SAGE Publications.

BROWN, J \& BARNETT, J. 2000. Facet theory: An approach to research. In Breakwell, GM, Hammond, S \& Fife-Schaw, C. (Eds). 2000. Research methods in psychology. London. SAGE Publications.

Caborn, A. If you decorate, can you be sure you will accumulate? Available on line. URL:http:// www.guardian.co.uk/money/2001/mar/25/ movinghouse.timetable. Accessed 19 May 2001. (Article on the Internet)

CANTER, D. 1969. An intergroup comparison of connotative dimensions in architecture. Environment and Behavior 1(1): 37-48.

CANTER, D. 1970. Need for a theory of function in architecture. The Architects' Journal Information Library (February): 299-302.

CANTER, DV \& DONALD, I. 1990. Temporal and trait facets of personnel assessment. Applied Psychology: An International Review 39(4): 413-429.

CANTER, D \& HERITAGE, R. 1990. A multivariate model of sexual offence behaviour: Developments in "offender profiling". Journal of Forensic Psychiatry 1 (2): 185-212.

CANTER, D \& THORNE, R. 1972. Attitudes to housing: A cross-cultural comparison. Environment and Behavior 4(9): 3-32.

CANTER, D \& WOOLS, R. 1970. A technique for the 
subjective appraisal of buildings. Building Science 5: 187-198.

CHOKER, BA. 1993. The meaning and use of housing: The traditional family. In Arias, EG. (Ed). 1993. The meaning and use of housing: International perspectives, approaches and their applications. Aldershot. Avebury.

CLARK, H \& CLARK, EV. 1977. Psychology and language: An introduction to psycholinguistics. New York. Harcourt Brace Jovanovich.

DEVLIN, K \& NASAR, JL. 1989. The beauty and the best: Some preliminary comparisons of "high" versus "popular" residential architecture and public versus architect judgments of same. Journal of Environmental Psychology 9: 333-344.

EAGLY, AH \& CHAIKEN, S. 1993. The psychology of attitudes. London. Harcourt Brace Jovanovich College Publishers.

EMMERSON, GJ \& NEELEY, MA. 1988. Two adaptable valid and reliable data-collection measures: Goal attainment scaling and the semantic differential. The Counseling Psychologist 16(2): 261-271.

GÄRLING, T. 1976. The structural analysis of environmental perception and cognition: A multidimensional scaling approach. Environment and Behavior 8(3): 385-415.

GIRALT-MIRACLE, D. 1975. New interiors 1. In Giralt -Miracle, D. (Ed) 1975. New interiors 1. Barcelona. Editorial Blume.

GRIMM, LG \& YARNOLD, PR. 1995. Introduction to multivariate statistics. In Grimm, LG \& Yarnold, PR. (Eds). 1995. Multivariate statistics. Washington. American Psychological Association.

HALL, R, PURCELL, AT, THORNE, R \& METCALFE, J. 1976. Multidimensional scaling analysis of interior, designed spaces. Environment and Behavior 8(4): 595 -600 .

HANYU, K. 1997. Visual properties and affective appraisals in residential areas after dark. Journal of Environmental Psychology 17(4): 301-315.

HAYES, N. 2000. Doing psychological research: Gathering and analysing data. Buckingham, Philadelphia. Open University Press.

HEIS, DR. 1969. Some methodological issues in semantic differential research. Psychological Bulletin 72 (6): 406-422.

HOMER, PM \& KAHLE, LR. 1988. A structural equation test of the value-attitude-behavior hierarchy. Journal of Personality and Social Psychology 54(4): 638-646.

HONIKMAN, B. 1971. An investigation of a method for studying personal evaluation and requirement of the built reinvent. In Honikman, B. (Ed). 1971. Proceedings of the architectural psychology conference at Kingston Polytechnic. London. RIBA Publications.

HORAYANGKURA, V. 1978. Semantic dimensional structures: A methodological approach. Environment and Behavior 10(4): 555-584.

KASMAR, JV. 1970. The development of a usable lexicon of environmental descriptors. Environment and Behavior 2(2): 153-169.

LITTLE, BR. 1987. Personality and the environment. In Stokols, D \& Altman, I. (Eds). 1987. Handbook of environmental psychology. Vol. 1. New York. Wiley \& Sons.
LYONS, E. 1998. Social psychology 1. In Eysenck, M. (Ed). 1998. Psychology: An integrated approach. London. Prentice Hall.

MARANS, RW \& SPECKELMEYER, KF. 1982. Measuring overall architectural quality: A component of building evaluation. Environment and Behavior 14 (6): 652-670.

MEHRABIAN, A \& RUSSELL, JA. 1974. The basic emotional impact of environments. Perceptual and Motor Skills 38: 283-301.

MERCER, W, HUNDLEBY, JD \& BENJAMIN, ML. 1980. Perception of physical aspects of homes, schools, neighbourhoods and university residence rooms. The Journal of Social Psychology 112: 103113.

NISSEN, L, FAULKNER, R \& FAULKNER, S. 1994. Inside today's home. Orlando. Harcourt Brace College Publishers.

OLSON, JM \& ZANNA, MP. 1993. Attitudes and attitude change. Annual Review of Psychology 44: 117154.

OPPENHEIM, AN. 1992. Questionnaire design, interviewing and attitude measurement. (New edition). London. Pinter.

ORNSTEIN, S. 1992. First impressions of the symbolic meanings connoted by reception area design.

Environment and Behavior 24(1): 85-110.

OSGOOD, CE, SUCI, GJ \& TANNENBAU, PH. 1957.

The measurement of meaning. Urbana, Chicago. University of Illinois press.

PEDERSEN, DM. 1986. Perception of interior designs. Perceptual and Motor Skills 63(2): 671-676.

RITTERFELD, U \& CUPCHIK, GC. 1996. Perceptions of interior spaces. Journal of Environmental Psychology 16: 349-360.

RUSSELL, JA, WARD, LM \& PRATT, G. 1981. Affective quality attributed to environments: A factor analytic study. Environment and Behavior 13(3):259-288. SCHIFFMAN, SS, REYNOLDS, ML \& YOUNG, FW. 1981. Introduction to multidimensional scaling: Theory, methods and applications. New York. Academic Press.

SHYE, S, ELIZUR, D \& HOFFMAN, M. 1994. Introduction to facet theory: Content design and intrinsic data analysis in behaviour research. London. SAGE Publications.

STALANS, LJ. 1995. Multidimensional scaling. In Grimm, LG \& Yarnold, PR. (Eds). 1995. Multivariate statistics. Washington. American Psychological Association.

SZALAY, LB \& DEESE, J. 1978. Subjective meaning and culture: An assessment through word associations. Hillsdale, New Jersey. Lawrence Erlbaum Associates.

WARD, LM \& RUSSELL, JA. 1981. Cognitive set and the perception of place. Environment and Behavior 13 (5): 610-632.

WILSON, MA \& CANTER, DV. 1990. The development of central concepts during professional education: an example of multivariate model of the concept of architectural style. Applied psychology: An International Review 39:431-455.

WOOLS, RM. 1969. The assessment of room friendliness. In Canter, D. (Ed). 1969. Architectural psychology. Proceedings of the conference held at Dalandhui, University of Strathclyde. London. RIBA Publications. 